\title{
Boron isotopic variations in hydrous rhyolitic melts: a case study from Long Valley, California
}

Published online: 19 November 2003

(C) Springer-Verlag 2003

\section{Contrib Mineral Petrol (2003) DOI 10.1007/s00410-003-0514-6}

Abstract section: the second sentence was given incorrect and is printed correctly here.

The following results indicate that pre-eruptive boron isotopic signatures were preserved in degassed glasses: (1) averaged secondary ionization mass spectrometry (SIMS) measurements of $\mathrm{H}_{2} \mathrm{O}$-rich $(\sim 3 \mathrm{wt} \%)$ melt inclusions from late erupted Bishop Tuff pumice are indistinguishable from positive thermal ionization mass spectrometry (PTIMS) analysis of vesiculated groundmass glass $\left(\delta^{11} \mathrm{~B}=+5.0 \pm 0.9 \%\right.$ and $+5.4 \pm 0.5 \%$, respectively); (2) SIMS spot-analyses on $\mathrm{H}_{2} \mathrm{O}$-poor obsidian $\left(\sim 0.15 \mathrm{wt} \% \quad \mathrm{H}_{2} \mathrm{O}\right)$ from younger Glass Mountain Dome YA (average $\delta^{11} \mathrm{~B}=+5.2 \pm 1.0 \%$ ) overlap with compositionally similar late Bishop Tuff melt inclusions; and (3) four variably degassed obsidian samples from the $0.6 \mathrm{ka}$ Mono Craters $\left(\mathrm{H}_{2} \mathrm{O}\right.$ between 0.74 and $0.10 \mathrm{wt} \%$ ) are homogeneous with regard to boron (average $\delta^{11} \mathrm{~B}=+3.2 \pm 0.8 \%$, MSWD $=0.4$ ).

Furthermore, the second sentence in paragraph two in section "Major and trace element compositions" was published incorrect. The correct sentence appears here.
For the Bishop Tuff, melt inclusion compositions from two individual pumice clasts are tightly grouped and closely match the field defined by the Anderson et al (2000) data which incorporated approximately five times more analyses from a stratigraphically comprehensive sample set (Fig. 3).

Unfortunately, the first sentence, last paragraph in section "Secondary boiling and degassing - boron variations in comparison with experimental results" was given incorrect. The correct sentence follows.

For post-caldera dome inclusions, the modeled gassaturated fractionation trends clearly fail to match measured variations, in particular for compatible trace elements such as $\mathrm{Sr}$ and $\mathrm{Ba}$ (Fig. 3G, H). Furthermore, a $\delta^{11} \mathrm{~B}$ shift of $-1.2 \%$ is predicted for $\sim 65 \%$ gas-saturated crystallization of South Deadman Dome FP rhyolite (i.e., from $\sim 25$ to $\sim 75 \mathrm{ppm} \mathrm{B}$; upper curve in Fig. 6). This compares unfavorably with the observed $-6.1 \pm 1.8 \%$ difference between IN01G and IN01 glasses. Alternatively, we thus suggest open-system mixing and/or assimilation to explain the overall $\sim 8 \%$ variations in $\delta^{11} \mathrm{~B}$ measured in Long Valley glasses.

The online version of the original article can be found at http:// dx.doi.org/10.1007/s00410-003-0514-6

A. K. Schmitt $(\bowtie)$ J J. I. Simon

Department of Earth and Space Sciences,

University of California Los Angeles,

Los Angeles, CA 90095-1567, USA

E-mail: axelk@gfz-potsdam.de

Tel.: + 49-0331-2881423

Fax: + 49-0331-2881474

A. K. Schmitt

Sektion 4.2 Anorganische und Isotopen-Geochemie,

GeoForschungsZentrum Potsdam, Telegrafenberg B123,

14473 Potsdam, Germany 